\title{
Fruit and Vegetable Safety-Microbiological Considerations
}

\author{
Michael P. Doyle \\ Food Research Institute and Department of Food Science, University of \\ Wisconsin-Madison, Madison, WI 53706
}

Microorganisms present two important problems to the vegetable and fruit industries. These include: 1) spoilage problems due to microbial degradation of produce that results in economic loss. and 2) human health problems due to the presence and/or growth of microbial pathogens that results in morbidity and mortality. Although both issues are of great concern to the produce industry, only the association of human pathogens with vegetables and fruits will be addressed here.

\section{TYPES OF MICROBIAL PATHOGENS ASSOCIATED WITH PRODUCE-RELATED ILLNESSES}

Many of the recognized food-related bacterial pathogens or toxins have been associated with human illnesses caused by eating contaminated vegetables or fruits. Examples include Bacillus cereus. Campylobacter jejuni, Clostridium botulinum neurotoxin, enterotoxigenic Escherichia coli, Listeria monocytogenes, Salmoneila, Shigella, and Staphylococcus aureus enterotoxin (Doyle, 1989). In addition, foodborne viruses such as hepatitis A also have been responsible for produce-related outbreaks. However. compared with other food groups, vegetables and fruits are infrequent vehicles of foodborne illness in the United States. The most recently reported information on outbreaks of foodborne disease provided by the U.S. Centers for Disease Control indicates that. in 1982, 25 of $279(9 \%)$ outbreaks in which a vehicle of transmission was identified were caused by fruits or vegetables (including four outbreaks attributed to poisonous mushrooms) (Macdonald and Griffin. 1986). Most outbreaks were due to botulism that resulted from eating improperly home-canned produce.

\section{INTRIGUING OUTBREAKS FROM EATING VEGETABLES OR FRUITS}

\section{Vegetable-related outbreaks}

Several outbreaks of gastroenteritis have been caused by eating fresh vegetables. Lettuce was the vehicle in three major outbreaks of shigellosis that occurred in Texas in 1983 and 1986 (Martin et al.. 1986; Davis et al., 1988). In one instance, two simultaneous outbreaks of Shigella sonnei gasroenteritis occurred at two Texas university campuses $97 \mathrm{~km}$ apart (Martin et al.. 1986). Tossed salads were determined to be associated with illness at both campuses. Students made salads from a self-serve bar and lettuce was believed to be the vehicle of transmission, since it was the only produce item known to be used in tossed salads in all of the cases. Unlike most outbreaks of shigellosis. these outbreaks were caused by a contami nated food source and not by a food handler.

A more recent lettuce-associated outbreak of $S$. sonnei gastroenteritis occurred in two west Texas counties in 1986 (Davis et al.. 1988). Three hundred forty-seven cases of shigellosis were associ ated with eating foods containing shredded lettuce and tomatoes at specific fast food restaurants. All implicated restaurants received shredded lettuce produced at one lettuce-shredding plant but differ ent lots of tomatoes were received by the restaurants. Investigation of the lettuce-shredding plant suggested that a food handler was the source of contamination and that the method of processing allowed cross-contamination to occur. Laboratory studies revealed that $S$. sonnei can survive on shredded lettuce at $5 \mathrm{C}$ for 3 days without a decrease in number. and for 7 days with only a $1-\log _{10}$ decrease. Shigelh grows well in shredded lettuce at $22 \mathrm{C}$. with a generation time of $1.1 \mathrm{hr}$ the organism increased for $1.4 \times 10^{3} \mathrm{cfu} / \mathrm{g}$ to $1.810^{6}$ $\mathrm{cfu} / \mathrm{g}$ in $12 \mathrm{hr}$.

Salads containing raw vegetables have been identified as important vehicles of traveler's diarrhea. an illness Americans often experience when visiting developing countries (Menon et al.. 1976). A prospective study of 73 physicians and 48 family members attend ing a medical conference in Mexico City in 1974 revealed that enterotoxigenic Escherichiu coli was the most common cause of illness. Fifty-nine (49\%) of the participants developed traveler's diarrhea, and eating salads containing raw vegetables was associated with enterotoxigenic $E$. coli infection.

Coleslaw was identified as the vehicle of the First conclusively documented foodborne outbreak of listeriosis (Schlech et al.. 1983). This outbreak occurred in the Maritime Provinces of Canada in 1981 and involved 34 perinatal cases and seven adult cases. In the perinatal cases, pregnant women generally developed acute febrile illness that was followed by abortion, with high mortality among the fetuses. Meningitis was the principal manifestation of illness in the adult cases. Listeria monocytogenes serotype $4 \mathrm{~b}$ was identified as the causative agent and the epidemic strain was isolated from coleslaw in the refrigerator of a patient and from two unopened packages of coleslaw from the same manufacturer as the patient's sample.

The coleslaw was prepared by a regional manufacturer with cabbages and carrots obtained from several wholesalers and many local farmers. A farmer was identified who raised cabbage and maintained a flock of sheep that had cases of listeriosis. Manure from the sheep was used to fertilize his cabbage fields. After the cabbage was harvested in October, it was held in a large cold-storage shed during the winter and early spring, until it was made into coleslaw. L. monocytogenes is a psychrotrophic bacterium that grows at refrigeration temperature. Inoculation studies by Beuchat et al. (1986) revealed the the organism can grow in raw, shredded cabbage during refrigerated storage. These investigators observed growth of L. monocytogenes (from $104 \mathrm{cfu} / \mathrm{g}$ to $10^{8} \mathrm{cfu} / \mathrm{g}$ ) in Cabbage held at $5 \mathrm{C}$ for 25 days. Hence- listeriae likely proliferated on the cabbage during cold storage before it was made into coleslaw.

Vegetable sprouts grown in a commercially sold seed sprouting kit were the vehicle of an outbreak of Bacillus cereus food poisoning (Portnoy et al., 1976). In 1973, four individuals developed $B$. cereus gastroenteritis within 6 to $15 \mathrm{hr}$ after eating raw soy. mustard. and cress sprouts. The sprout-s were grown at $22 \mathrm{C}$ for 3 days in a home seed sprouting kit purchased at a health food store. Laboratory studies revealed that $B$. cereus on unsprouted seeds pro liferated during germination and reached levels of $8 \times 10^{4}$ to $7.6 \times$ $10^{7} \mathrm{cfu} / \mathrm{g}$.

Recently, four outbreaks of staphylcoccal food poisoning were associated with eating imported canned mushrooms from the Peoples' Republic of China (Collins et al.. 1989). The outbreaks included: a) 22 cases from eating mushrooms in omelets or hamburg ers at a university cafeteria in Starksville. Miss., b) 48 cases from eating mushrooms from a salad bar at a hospital cafeteria in Queens. N.Y.. c) 12 cases from eating mushrooms in pizza or parmigiana sauce at a restaurant in McKeesport, Pa.. and d) 20 cases from eating mushrooms on pizza at a pizzeria in Philipsburg. Pa. All of the problem mushrooms were packaged in no. 10 cans that were processed in China. Some small producers of Chinesegrown mushrooms were found to hold fresh mushrooms in high salt 
solutions for long periods of time. The mushrooms were subsequently canned after a long period of temperature abuse. Investigators speculate that staphylococcal enterotoxin was pro duced in mushrooms during storage in the salt solution and that the toxin remained active after thermal processing.

\section{Fruit-related outbreaks}

Historically, fruits have had an exceptionally good public health record. This may largely be attributed to the natural defense mech anisms that many fruits possess. Mechanisms that prevent fruitborne transmission of pathogens include the thick skin of many fruits, which is usually removed or thoroughly washed before the fruit is eaten, and antimicrobial substances such as essential oils and/or organic acids that often maintain the $\mathrm{pH}$ at $<4.6$ (Goepfert, 1980). However, there have been occasional food-related illnesses caused by pathogens or bacterial toxins in fruit.

Canned fruits are among the safest of foods. However, a few outbreaks of botulism have occurred from home-canned pimentos, figs, blackberries. peaches, and tomatoes (Goepfert 1980). These are fruits whose $\mathrm{pH}$ is above the critical 4.6 to 4.8 for growth of $C$. botulinum or were situations where molds or acid-metabolizing bacteria contaminated the product and used the organic acid of the fruit to raise the $\mathrm{pH}$ above the critical level (Mundt and Norman, 1982; Montville, 1982; Odlaug and Pflug. 1979). An example is botulism from home-canned tomatoes. Tomatoes are a high-acid food usual ly in the $\mathrm{pH}$ range of 4.0 to 4.6, which normally would not allow botulinal toxin production (Fields et al., 1977; Mundt et al., 1978). However, since 1899 , at least 17 outbreaks have been reported that were due to home-canned tomato products (Odlaug and Pflug. 1979). The major problem has been due to jars or cans with poor seals or low vacuum and minimally heat-processed. Molds contam inating product after heating or bacteria such as Bacillus licheniformis that survive in product receiving a minimal heat treatment can metabolize citric acid and increase the $\mathrm{pH}$ to allow growth of C. botuinum (Montville, 1982; Mundt and Norman, 1982; Odlaug and Pflug, 1979).

Outbreaks of salmonellosis also have been caused by fruit products. An outbreak in England in 1961 was associated with eating marshmallow cookies (Semple et al., 1961). The source of the Salmonella was desiccated coconut sprinkled on the cookies. Subsequent analysis of shipments of desiccated coconut from Ceylon revealed that $479(4.8 \%)$ of 9265 samples were contaminated with Salmonella. Another interesting outbreak occurred in New
Jersey in 1974. and was caused by Salmonella- contaminated chilled, nonsterile apple juice ( $\mathrm{pH}$ 3.4-3.9) (Morbidity and Mortality, 1975). The source of the salmonellae was thought to be animal manure that was used to fertilize the orchards. Salmonellae contaminated the juice because of failure to clean and sterilize the pro cessing equipment. Subsequent studies by Goverd et al. (1979) re vealed that salmonellae could grow at $22 \mathrm{C}$ in apple juice at $\mathrm{pH} 3.7$. A solution to this problem is to pasteurize apple juice.

An unusual outbreak of 24 cases of hepatitis A occurred in Aberdeen, Scotland, in 1983 (Reid and Robinson. 1987). Raspberry mousse prepared from frozen raspberries at a local hotel was identified as the source of infection. The raspberries had been gathered from several farms, and three of the producers had been implicated indirectly in a previous outbreak. It was presumed that the contamination occurred either at the time of picking or packing of the raspberries, probably by a virus excreter among the pickers.

\section{SOURCES OF MICROBIAL PATHOGENS CAUSING PRO- DUCE-ASSOCIATED ILLNESSES}

Microbial pathogens contaminate produce through three princi pal sources. These include soil, feces, and food handlers. Several pathogens, including B. cereus. C. Botulinum. and L. monocytogenes. are soil-borne and are often present on vegetables and fruits that contact soil. Untreated human or animal fecal wastes that are used for fertilizer or irrigation are sources of $C$. jejuni. enterotoxigenie E. coli, L. monocytogenes, Salmonella, Shigella. and hepatitis A virus. Food handlers can be fecal carriers of microbial pathogens and may contaminate fruits and vegetables during picking, packing, or food preparation. pathogens such as $C$. jejuni. enterotoxigenic E. coli. Salmonella, Shigella. S. aureus. and hepatitis A virus are known to be carried by food handlers and have been causes of veg etable- or fruit-associated illnesses.

\section{PRESENCE OF PATHOGENS ON VEGETABLES}

Many surveys have been done to determine the incidence of bacterial pathogens on vegetables. Examples of results of such studies arc shown in Table 1. These results represent studies in which pathogens were detected; results of many surveys not reported indi cate that no pathogens were found. Hence. although in some instances a substantial percentage of certain vegetables assayed was contaminated with pathogens. most vegetables arc pathogen-free.

Table 1. Presence of bacterial pathogens on vegetables.

\begin{tabular}{|c|c|c|c|c|}
\hline Vegetable & Country & Pathogen & Prevalence & Reference \\
\hline $\begin{array}{l}\text { Dried asparagus } \\
\text { Artichoke } \\
\text { Cabbage } \\
\text { Cabbage } \\
\text { Celery } \\
\text { Chili } \\
\text { Cucumbers } \\
\text { Fennel } \\
\text { Letuce } \\
\text { Lettuce } \\
\text { Lettuce } \\
\text { Dried mushrooms } \\
\text { Fresh mushrooms } \\
\text { Potatoes } \\
\text { Radishes } \\
\text { Prepacked salads } \\
\text { Vegetables } \\
\text { Vegetables } 2\end{array}$ & $\begin{array}{l}\text { Taiwan } \\
\text { Spain } \\
\text { Spain } \\
\text { United States } \\
\text { Spain } \\
\text { Surinam } \\
\text { United States } \\
\text { Italy } \\
\text { Italy } \\
\text { Netherlands } \\
\text { Spain } \\
\text { China/Taiwan } \\
\text { United States } \\
\text { United States } \\
\text { United States } \\
\text { England } \\
\text { Spain } \\
\text { United States }\end{array}$ & $\begin{array}{l}\text { Salmonella } \\
\text { Salmonella } \\
\text { Salmonella } \\
\text { Listeria monocytagenes } \\
\text { Salmonella } \\
\text { Saimonella } \\
\text { Listeria monocytogenes } \\
\text { Salmonella } \\
\text { Saimonella } \\
\text { Salmonella } \\
\text { Salmonella } \\
\text { Salmonella } \\
\text { Campylobacter jejuni } \\
\text { Listeria monocytogenes } \\
\text { Listeria monocytogenes } \\
\text { Listeria monocytogenes } \\
\text { Salmonella } \\
\text { Salmonella }\end{array}$ & $\begin{array}{l}11 / 48(22.9 \%) \\
3 / 25(12.0 \%) \\
7 / 41(17.1 \%) \\
1 / 92(1.1 \%) \\
2 / 26(7.7 \%) \\
5 / 16(31.3 \%) \\
2 / 92(2.2 \%) \\
64 / 89(71.9 \%) \\
82 / 120(68.3 \%) \\
2 / 28(7.1 \%) \\
5 / 80(6.3 \%) \\
11 / 162(6.8 \%) \\
3 / 200(1.5 \%) \\
28 / 132(21.2 \%) \\
19 / 132(14.4 \%) \\
4 / 60(13.3 \%) \\
46 / 849(5.4 \%) \\
4 / 50(8.0 \%)\end{array}$ & $\begin{array}{l}\text { Bockmühl and Wohlus (1984) } \\
\text { Garcia-Villanova Ruiz et al. (1984b) } \\
\text { Garcia-Villanova Ruiz et al. (1987b) } \\
\text { Heisick et al. (1989) } \\
\text { Garcia-Villanova Ruiz et al. (1987b) } \\
\text { Tamminga et al. (1978) } \\
\text { Heisick et al. (1989) } \\
\text { Ercolani (1976) } \\
\text { Ercolani (1976) } \\
\text { Tamminga et al. (1978) } \\
\text { Garcia-Villanova Ruiz et al. (1987b) } \\
\text { Bockmulhl and Schoeni (1986) } \\
\text { Doyle and Schoeni (1986) } \\
\text { Heisick et al. (1989) } \\
\text { Heisick et al. (1989) } \\
\text { Sizmur and Walker (1988) } \\
\text { Garcia-Villanova Ruiz ct al. (1987a) } \\
\text { Rude et al. (1984) }\end{array}$ \\
\hline
\end{tabular}

${ }^{2}$ Celery, carrots, radishes, and spinach. 


\section{POTENTIAL FUTURE MICROBIOLOGICAL SAFETY CONCERNS ABOUT VEGETABLES AND FRUITS}

Looking ahead. as researchers develop and food producers and processors apply new innovations to growing, processing, and marketing produce, the vegetable and fruit industries should evaluate the microbiological risks these changes in technology introduce. Examples of technological changes that could lead to microbiologi cal safety problems if appropriate measures are not taken to assure safety include: 1) the reduction of naturally occurring preservatives through genetic improvement of crops. 2) innovations in packaging to extend shelf life, and 3) producing refrigerated cooked products that have an extended shelf life.

Reduction of naturally occurring preservatives, Many plants (including their seeds and fruits) contain antimicrobial substances that inhibit growth of spoilage microorganisms and/or human pathogens. For example, cranberries contain benzoic acid. which is a mold inhibitor; wheat endosperm contains purothionins, which inhibit yeasts and some human pathogens; cocoa beans and many fruits contain anthocyanins, which inhibit many types of bacteria; and tomatoes contain $\alpha$ - tomatine, which inhibits fungi and bacteria. In addition, many fruits contain high levels of organic acid(s) that prevent the growth of microbial pathogens. Consideration should be given to changes that may occur in expression of preservatives when plant genes are manipulated for strain improvement. Reduced levels of preservatives may result in more rapid spoilage of produce by microorganisms and/or food safety problems.

An example of a potential food safety problem would be the re duction of the acid levels of tomatoes. Tomatoes normally contain high levels of acid ( $\mathrm{pH}$ 4.0-4.6) that provide protection against growth and toxin production by $C$. botulinum. Many home canners do not heat tomato products sufficiently to kill spores of $C$. botulinum. Developing low-acid $(>\mathrm{pH} 4.8)$ tomatoes. which may re sult through advances in plant breeding, may lead to a botulinal toxin hazard.

\section{POTENTIAL PROBLEMS WITH INNOVATIONS IN PACK- AGING AND STORING FOODS}

Because of the high perishability of most vegetables and fruits, the produce industry is very interested in applying new technologi cal developments that would extend the shelf life of products. Many successful methods have been developed to greatly extend product shelf life; however, care must be taken to consider the potential microbiological risks associated with such practices. There are several examples of brilliant technological innovations that pro long product shelf life, but also present serious health risks. For instance, a process was developed in Europe that uses pasteurization to produce vacuum-packed, lightly cooked potatoes that could be stored for 2 to $3 \mathrm{~min}$ at room temperature (Lund et al., 1988). The process involves: a) pasteurizing the product at 75 to $85 \mathrm{C}$ for 5 to 15 min. b) vacuum-packaging the product in plastic pouches, c) holding the product at 25 to $35 \mathrm{C}$ for 14 to $24 \mathrm{hr}$ to allow germination of spores. and d) pasteurizing the product at 85 to $90 \mathrm{C}$ for 25 to 35 min. Inoculation studies revealed that $C$. botulinum spores could survive the process and form toxin within 5 to 9 days at 25C (Lind et al., 1988). Potatoes that are packaged and processed under such conditions must be held refrigerated $(<4 \mathrm{C})$ or treated with a preser vative (such as acidified to $<\mathrm{pH} 4.6$ ) to control $C$. botulinum (Notermans et al., 1985; Dodds, 1989).

Another example of the use of a novel packaging idea was to wrap containers of fresh mushrooms with a polyvinyl chloride (PVC) stretch film. Respiration of the mushrooms consumes the oxygen within the package, thereby creating an anaerobic environment. This greatly extends the shelf life of the mushrooms because oxygen is required for enzymatic browning to occur. However, this anaerobic environment also provides conditions for toxin production by $C$. botulinum. Inoculation studies by Sugiyama and Yang (1975) revealed that botulinal toxin was produced in PVC filmpackaged mushrooms held at 20C for 3 to 4 days, and that the toxic mushrooms appeared to be edible. Subsequent studies revealed that placing two 3.2-mm holes in the overwrap of the package prevents toxin formation (Sugiyama and Rutledge, 1978; Kautter et al., 1978). Although placing holes in the PVC film reduces the greatly extended shelf life of film-wrapped mushrooms. it is now common practice to put these holes in the package to prevent $C$. botulinum growth.

Controlled atmosphere storage (CAS) of vegetables is another innovation that extends shelf like. Usually, CAS of vegetables uses a lower oxygen concentration and higher carbon dioxide concentration than that normally found in air CAS decreases the rate of veg etable respiration, thereby retarding ripening and facilitating the re tention of higher quality for a longer period of time than would occur under an atmosphere of air. Although the economic benefits of CAS are apparent, the microbiological safety risks are not. Listeria monocytogenes is a soilborne bacterial pathogen that can grow at refrigeration temperature (4C) and frequently contaminates vegetables (Heisick et al., 1989). Additionally, growth of the organism is enhanced in an environment with decreased oxygen concentrations and supplemented with carbon dioxide (Doyle, 1988). Hence, conditions of a CAS environment may enhance the growth of $L$. monocytogenes on vegetables.

Inoculation studies by Bet-rang et al. (1989) were done to evaluate the fate of L. monocytogenes on fresh asparagus, broccoli, and cauliflower held under CAS at 4 or 15C. Studies revealed that CAS at $15 \mathrm{C}$ lengthened the time that vegetables were acceptable for consumption by 2 to 4 days, and at $4 \mathrm{C}$ by 1 week. Although CAS did not influence the growth rate of $L$. monocytogenes, the organism continued to grow on asparagus during extended storage and increased by 1 - to $1.5-\log _{10} / \mathrm{g}$ during the extended shelf life.

\section{POTENTIAL PROBLEMS WITH REFRIGERATED, COOKED FOODS WITH EXTENDED SHELF LIFE}

With today's active lifestyle, time to prepare meals at home has become quite limited. Hence, today's consumer has a market-driv ing interest in convenient. easy-to-prepare foods. The food industry anticipates meeting this demand by marketing a variety or precooked foods that are packaged for extended shelf life and preserved principally by refrigeration. Such foods carry considerable microbiological risks if they are not properly prepared and controlled. The principal microbiological concerns are $C$. botulinum. L. monocytogenes, and Yersinia enterocolitica. There are two types of $C$. botulinum, i.e., proteolytic and nonproteolytic. that differ in the heat resistance of their spores as well as in their ability to grow at refrigeration temperature. The proteolytic types are more heatresistant (spores can survive boiling) and cannot grow at $4 \mathrm{C}$, whereas the nonproteolytic types are more heat-sensitive (spores usually are killed at 100C) and can grow at 4C.

The heat treatment given such foods is usually not sufficient to kill spores of proteolytic $C$. botulinum. Hence, it must be assumed that active spores are present after cooking. The heat treatment given the food typically is sufficient to kill most vegetative bacterial competitors, and this would make the food a medium conducive for botulinal toxin production if the food were temperature-abused (held unrefrigerated). Although nonproteolytic C. botulinum spores are more heat-sensitive than the poteolytic types. the heat treatment given many cooked foods is often inadequate to kill these spores.

Nonproteolytic C. botulinum. L. monocytogenes. and Y. enterocolitica are psychrotrophic bacteria, which means that they can grow at refrigeration temperature. Both L. monocytogenes and Y. enterocolitica are vegetative bacteria that do not require as severe a heat treatment for inactivation as the spore-forming $C$. botulinum. To prevent the psychrotrophic vegetative bacteria from proliferating in cooked foods. such foods should be given sufficient heat treatment to destroy these organisms. It may not be possible to provide enough heat to foods to kill spores of nonproteolytic $C$. botulinum and still have an organoleptically acceptable product. Hence. consideration must be given to means of preventing toxin formation by nonproteolytic $C$. botulinum during refrigerated storage. Restricting the shelf life of the product to a time that would not allow toxin formation is one alternative. 
Toxin formation by proteolytic $C$. botulinum can be prevented by proper refrigeration (4C). However, if refrigeration is the sole means of preserving the product, excellent temperature control is essential as is a means of detecting temperature abuse so that abused products can be identified and destroyed. Ideally. the means of identifying temperature abuse should be interpretable by the consumer because the product may not be properly refrigerated in the home. Appropriately designed time-temperature integrators may serve as useful indicators of temperature abuse. Ideally. for safety, at least one other protective factor (beyond refrigeration) should be included to control C. botulinum. Examples of such protective factors include an antibotulinal agent such as sodium nitrite, acid to re duce $\mathrm{pH}$ below 4.6, or humectants to lower the water activity below 0.93 .

Two recent botulism outbreaks caused by a garlic-in-oil product illustrate the importance of proper refrigeration of perishable foods. The outbreaks included 36 cases of type B botulism from eating garlic buttered bread at a restaurant in Vancouver, B.C., in 1985 (St. Louis et al.. 1988) and three cases of botulism in 1989 in New York from garlic buttered bread eaten at home. The vehicle in both out breaks was a chopped garlic-in-soybean oil product. The product was bottled and labeled as "Keep Refrigerated" in very small print. In both outbreaks, the product was held at room temperature. Inoculation studies revealed that botulinal toxin could be produced in 15 days in product with 1 C. botulinum spore/g of garlic and held at 35C (Solomon and Kautter. 1988). The appearance and odor of the toxic product was acceptable. and the product would likely have been consumed. The U.S. Food and Drug Administration recently has banned the sale of garlic-in-oil products that require refrigeration for safety. Products acidified to below pH 4.6 are considered safe and marketable.

\section{CONCLUDING REMARKS}

Clearly, past history indicates that bacterial pathogens can be associated with vegetables and fruits and cause illness. Although most produce is likely free of pathogens. food processors cannot be complacent and must take appropriate measures to assure food safety. A well-designed and properly implemented hazard analysis crit ical control point (HACCP) program is the best approach a food processor can take to produce a microbiologically safe product. Many recent advances in food technology have resulted in products with increased quality and/or increased shelf life. However, many of these innovations have potential microbiological risks associated with them. Hence, it is important that the vegetable and fruit indus tries fully evaluate the microbiological risks associated with new in novations in growing, processing, and marketing produce before adopting such practices for routine use.

\section{Literature Cited}

Berrang. M.E., R.E. Brackett, and LR. Beuchar. 1989. Growth of Listeria monocyfogenes on fresh vegetables stored under controlled-atmosphere. J. Food Protect. 54:702-705.

Beuchal. LR.. R.E. Brackett. D.Y.-Y. Hao, and D.E. Conner. 1986. Growth and thermal innovation of Listeria monocytogenes in cabbage and cabbage juice. Can. J. Microbiol. 32:791-795.

Bockemuhl. J. and B. Wohlers. 1984. Zur Problematik der Kontamination unbehandelter Trockenprodukte der Lebensmittelindustrie mit Salmonellen. Zentralbl. Bakteriol. Hyg.. I. Abt. Orig. B. 178:535-541.

Collins, R.K.. M.N. Hendenon. D.E. Conwill. F.E. Thompson. M.E. Garland, S. Schultz, J.J. Campana, L.D. Budnick, J.J. Guzewich, D.L. Morse, M.J. Diskin. T.L Hays, J.A. Kail. J.R. Rager, R.R. Willenpart, G. Wells, A.S. Trantini,, J.M. Zimmerman, J. Crumrine. G.E. Ware, M. Dorman. and D.R Tavis. 1989. Multiple outbreaks of staphylococcal food poisoning caused by canned mushrooms. Morbid. Mortal. Weekly Rpt. 38(24):417-418.

Davis. H., J.P. Taylor. J.N. Perdue, G.N. Stelma, Jr.. J.M. Humphreys. Jr.. R Rowntree III, and K.D. Greene. 1988. A shigellosis outbreak traced to commercially distributed shredded lettuce. Amer. J. Epidemiol. 128: 1312-1321
Dodds, K.L. 1989. Combined effect of water activity and $\mathrm{pH}$ on inhibition of toxin production by Clostridium botulinum in cooked, vacuumpacked potatoes. Applied Environ. Micobiol. 55:656-660.

Doyle, M.P. (ed.) 1989. Foodborne bacterial pathogens. Marcel Dekker. New York.

Doyle, M.P. 1988. Effect of environmental and processing conditions on Listeria monocytogenes. Food Technol. 42(4):169- 171.

Doyle, M.P. and J.L. Schoeni. 1986. Isolation of Campylobacter jejuni from retail mushmoms. Applied Environ. Microbiol. 51: 449-450.

Ercolani, G.L. 1976. Bacteriological quality assessment of fresh marketed lettuce and fennel. Applied Environ. Micrcbiol. 31: 847-852.

Fields. M.L.. A.F. Zamora, and M. Bradsher. 1977. Microbiological analysis of home-canned tomatoes and green beans. J. Food Sci. 42:931934.

Garcia-Villanova Ruiz, B., A. Cueto Espinar. and M.J. Bolanos. 1987a. A comparative study of strains of Salmonella isolated from irrigation waters, vegetables and human infections. Epidemiol. Infect. 98:271-276.

Garcia-Villanova Ruiz, B.. R. Galvez Vargas. and R. Garcia-Villanova. 1987b. Contamination on fresh vegetables during cultivation and marketing. Intl. J. Food Microbiol. 4:285-291

Goepfert. J.M. 1980. Vegetables, fruits, nuts, and their products. p. 606642. In: International Commission on Microbiological Specifications for Foods (cd.). Microbial ecology of foods. vol. II. Academic, New York.

Goverd, K.A., F.W. Beech, R.P. Hobbs, and R. Shannon. 1979. The occurrence and survival of coliforms and salmonellas in apple juice and cider. J. Applied Bacterial. 46:521-530

Heisick, J.E.. D.E. Wagner, M.L. Nierman. and J.T. Peeler. 1989. Listeria spp. found on fresh market produce. Applied Environ. Microbiol. 55: 1925-1927.

Kautter. D.S.. T. Lilly Jr.. and R. Lynt 1978. Evaluation of the botulism hazard in fresh mushroom wrapped in commercial polyvinylchloride film. J. Food Protect 41:120-121.

Lund, B.M., A.F. Graham, and S.M. George. 1988. Growth and formation of toxin by Clostridium botulinurn in peeled, inoculated, vacuum-packed potatoes after a double pasteurization and storage at $25 \mathrm{C}$. J. Applied Bacteriol. 64:241-246.

MacDonald, K.L and P.M. Griffin. 1986. Foodborne disease outbreaks, annual summary, 1982. Morbid. Mortal. Weekly Rpt. 35:7SS-16SS. (Suppl. ISS.)

Martin. D.L.. T.L. Gustafson, J.W. Pelosi. L. Suarez, and G.V. Pierce. 1986. Contaminated produce-a common source for two outbreaks of Shigella gastroenteritis. Amer. J. Epidemiol. 124:299-305.

Merson, M.H., G.K. Morris, D.A. Sack, J.G. Wells, J.C. Feeley. R.B. Sack, W.B. Creech. AZ. Kapikian. and E.J. Gangarosa. 1976. Travelers diarrhea in Mexico. New Engl. J. Med. 294:1299-1305.

Montville, T.J. 1982. Metabolic effect of Bacillus licheniformis on Clostridium botulinum: Implications for home-canned tomatoes. Applied Environ. Microbiol. 44:334-338.

Morbidity and Mortality. 1975. Epidemiologic notes and reports, Salmonella typhimurium outbreak traced to a commercial apple cider--.New Jersey. Morbid. Mortal. Weekly Rpt. 24:87.

Mundt. J.O., J.L. Collins, I.E. McCarty. and R. Bailey. 1978. Description and microbiology of home-canned tomatoes and tomato juice. J. Food Protect. 41:944-947.

,Mundr. J.O. and JM. Norman. 1982. Metabiosis and $\mathrm{pH}$ of moldy fresh tomatoes. J. Food Protect 45:829-832.

Notermans. S., J. Dufrenne. and M.J.H. Keyberts. 1985. Use of preservatives to delay toxin formation by Clostridium botulinum (type B, strain Okra) in vacuum-packed, cooked potatoes. J. Food Protect 48:851-855.

Odlaug, T.E. and I.J. Pflug. 1979. Clostridium botulinum growth and toxin production in tomato juice containing Aspergillus gracilis. Applied Environ. Microbiol. 37:496-504.

Portnoy, B.L., J.M. Goepfert. and S.M. Harmon. 1976. An outbreak of Bacillus cereus food poisoning resulting from contaminated vegetable sprouts. Amer. J. Epidemiol. 103:589-594.

Reid, T.M.S. and H.G. Robinson. 1987. Frozen raspberries and nepalitis A. Epidemiol. Infect. 98:109-112.

Rude, R.S.. G.J. Jackson, J.W. Bier, T.K. Sawyer. and N.G. Risty. 1984. Survey of fresh vegetables for nematodes. amoebae, and Salmonella. J. Assn. Offic. Anal. Chem. 67:613-615.

Schlech. W.F.. III. P.M. Lavigne. R.A. Bonolussi. A.C. Allen, E.V. Haldane, A.J. Wort. A.W. Hightower, S.E. Johnson. S.H. King, E.S Nicholls, and C.V. Broome. 1983. Epidemic listeriosis: evidence for transmission by food. New Engl. J. Med. 308:203-206.

Semple. A.B.. W.H. Parry, and A.J. Graham. 1961. Paratyphoid fever traced to desicated coconut. Lancet ii:364-365.

Sizmur, K. and C.W. Walker. 1988. Listeria in prepacked salads. Lancet i:1167. 
Solomon. H.M. and D.A. Kautter. 1988. Outgrowth and toxin production by Clostridium botulinum in bottled chopped garlic. J. Food Protect. 51:562-865.

St. Louis, M.E.. S.H.S. Peck. D. Bowering, G.B. Morgan. J. Blatherwick. S. Banerjee, G.D.M. Kettyls. W.A. Black, M.E. Milling. A.H.W. Hauschlld, R.V. Tauxe. and P.A. Blake. 1988. Botulism from chopped garlic: delayed recognition of a major outbreak. Ann. Int. Med. 108: 363-368.

Sugiyama. H. and K.H. Yang. 1975. Growth potential of Clostridium bo- tulinum in fresh mushrooms packaged in semipermeable plastic film. Applied Microbiol. 30:964-969.

Sugiyama. H. and K.S. Rutledge. 1978. Failure of Clostridium botulinum to grow in fresh mushrooms packaged in plastic overwrap with holes. J. Food Protect. 41:348-350.

Tamminga. S.K.. R.R. Beumer. and E.H. Kampelmacher. 1978. The hygienic quality of vegetables grown in or imported into the Netherlands: A tentative survey. J. Hyg. 80:143-154. 